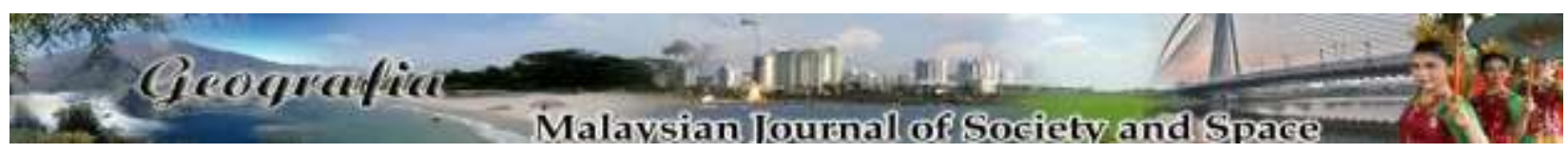

\title{
Perancangan dan pengujian pemindahan pengguna melalui simulasi tindakbalas kecemasan 3D
}

\author{
Syed Ahmad Fadhli Syed Abdul Rahman ${ }^{1}$, Khairul Nizam Abdul Maulud ${ }^{1,2}$, \\ Sharifah Nurul Ain Syed Mustorpha ${ }^{3}$ \\ ${ }^{1}$ Pusat Pencerapan Bumi, Institut Perubahan Iklim (IPI), Universiti Kebangsaan Malaysia, \\ ${ }^{2}$ Jabatan Kejuruteraan Awam, Fakulti Kejuruteraan dan Alam Bina, Universiti Kebangsaan Malaysia, \\ ${ }^{3}$ Pusat Pengajian Sains Ukur dan Geomatik, Fakulti Senibina, Perancangan dan Ukur, \\ Universiti Teknologi Mara
}

Correspondence: Khairul Nizam Abdul Maulud (email: knam@ukm.edu.my)

Received: 03 March 2020; Accepted: 25 July 2020; Published: 28 August 2020

\begin{abstract}
Abstrak
Proses pemindahan pengguna ketika situasi kecemasan amat penting seiring dengan pembangunan struktur bertingkat yang mampan. Proses memindahkan pengguna adalah mencabar kerana melibatkan perkara-perkara luar kawalan seperti tingkahlaku pengguna dan faktor dinamik kemalangan. Kajian ini dilaksanakan bagi merancang dan menguji proses pemindahan pengguna didalam persekitaran 3D. Ia merangkumi tiga fasa iaitu fasa integrasi data, pembangunan dan pengujian topologi dan analisa simulasi. Pengujian kaedah integrasi model 3D BIM kepada 3D GIS dilakukan dengan menggunakan kaedah Revit ke Feature Manipulation Engine (FME) dan seterusnya ke Multipatch Shapefile dipilih sebagai kaedah terbaik kerana memenuhi keperluan analisa kecemasan. Seterusnya, jaringan topologi kekisi dibina dan diuji melalui ujian ketersediaan dan ujian ketepatan. Purata kadar ketersediaan akses dikenalpasti melebihi $12 \%$ manakala purata keralatan dikenalpasti sebanyak $3.18 \%$. Pengiraan jarak ke akses keluar dan saiz kekisi 0.38 m digunakan sebagai input parameter dalam fasa ketiga. Tiga parameter digunakan iaitu kelajuan, kapasiti pengguna dan pemilihan akses diuji dalam lapan simulasi yang berbeza. Hasil simulasi diperincikan kedalam dua faktor iaitu masa dan ruang kritikal. Faktor masa mengupas kesan kapasiti pengguna dan pemilihan akses terhadap masa. Kesan kapasiti pengguna didapati semakin besar apabila tempoh masa pemindahan pengguna bertambah. Kaedah pembahagian akses dikenalpasti sebagai kaedah terbaik untuk memindahkan pengguna dengan purata 17\% lebih pantas berbanding kaedah lain. Faktor ruang kritikal melibatkan pengenalpastian ruang kritikal didalam bangunan melalui peta haba dan teori Level of Service. Pengenalpastian ruang kritikal dikenalpasti berpunca daripada akses yang berkelebaran kurang dari 1.5 meter bagi setiap aras. Pengujian pelebaran akses diuji dan dibuktikan mampu menambahbaik aliran pemindahan pengguna dalam kajian ini.
\end{abstract}

Kata kunci: 3D, akses, BIM, GIS, kecemasan, topologi 
GEOGRAFIA Online ${ }^{\mathrm{TM}}$ Malaysian Journal of Society and Space 16 issue 3 (147-166)

(C) 2020, e-ISSN 2682-7727 https://doi.org/10.17576/geo-2020-1603-12

\title{
Planning and evaluation of user evacuation through 3D emergency response simulation
}

\begin{abstract}
The process of evacuating users in emergency management is very important, in line with the development of a sustainable multi-level structure. It is challenging because they are tied to things beyond control such as user behavior and dynamic factors of an accident. This study is conducted to design and evaluate the user evacuation process in a $3 \mathrm{D}$ environment. It involves three phases namely data integration phase, topology development and testing, and simulation analysis. Methods of integrating 3D BIM models into 3D GIS were tested and the integration method from Revit to Feature Manipulation Engine (FME) to Multipatch Shapefile was chosen as the best method because it met the needs of emergency analysis. Next, the topology network is developed and tested through availability and accuracy test. The average availability access is more than $12 \%$ while the error rate detected is $3.18 \%$. The distance measured for the nearest exit and the $0.38 \mathrm{~m}$ lattice size is used as a parameter input in the third phase. Three parameters namely speed, user capacity and access selection were tested in eight different simulations. The simulation results are summarized into two factors: time and space critical. Time factors elaborate on the impact of user capacity and selection of access towards time. The effect of user capacity would be greater as the duration of user evacuation increases. The divide access method was identified as the best way to evacuate users on average of $17 \%$ faster than other methods. Critical space factors discussed the identification of critical spaces through heat maps and the Level of Service theory. The critical spaces were identified due to access with less than 1.5 meters width at each level. Through access widening testing has proven can improve user evacuation flow in this study.
\end{abstract}

Keywords: 3D, access, BIM, emergency, GIS, topology

\section{Pengenalan}

Seiring dengan peningkatan kadar pembangunan bangunan bertingkat, aktiviti pemindahan pengguna ketika kecemasan menjadi kajian utama khususnya bagi perancang pengurusan kecemasan dan pembuat polisi. Pemindahan sekumpulan pengguna dalam satu-satu masa dengan cara yang efektif adalah tidak mudah khususnya apabila melibatkan persekitaran dalaman disebabkan tingkahlaku pengguna dinamik dan pelbagai (Kadir et al., 2019). Oleh itu, adalah penting untuk menyediakan pelan pemindahan yang mesra pengguna dan efisien bagi keselamatan pengguna dalam bangunan.

Pelan pemindahan ini amat penting terutama bagi tujuan ketepatan perancangan laluan. Ketepatan perancangan laluan pemindahan bagi tindak balas kecemasan bergantung kepada ketelitian data geospatial dan model struktur rangkaian. Pada masa ini, data model Sistem Maklumat Geografi (GIS) digunakan secara meluas dalam membangunkan rangkaian laluan dalaman dengan memberi tumpuan kepada visualisasi geometri. Berbeza dengan data model Permodelan Maklumat Bangunan (BIM) dimana maklumat semantik merupakan perkara yang dititikberatkan didalam pembangunan model BIM (Volk et al., 2014). Maklumat geometri dan 
semantik boleh dihubungkan antara satu sama lain untuk memberi keseimbangan dalam merancang aktiviti pemindahan pengguna ketika kecemasan (Abdul Rahman et al., 2020).

Apabila teknologi kedudukan (positioning technology) berkembang pada masa kini, perkhidmatan berasaskan lokasi atau location-based services (LBS) juga berkembang dari persekitaran luaran ke persekitaran dalaman (Lin \& Lin, 2018). Bagi merangka jaringan topologi untuk persekitaran dalaman, terdapat beberapa konsep yang digunakan seperti visibility graph (Kneidl et al., 2012), straight skeletons (Taneja et al., 2016) dan lain-lain. Namun konsep-konsep tersebut adalah terhad dan tindak menyeluruh. Oleh itu, jaringan topologi 2D berasaskan kekisi seperti yang dicadangkan oleh $\mathrm{Li}$ et al., (2010) digunapakai tetapi diadaptasi kedalam persekitaran 3D. Jaringan kekisi dipilih berdasarkan kebolehupayaan untuk meliputi ke seluruh permukaan lantai bangunan sekaligus menawarkan jaringan topologi yang menyeluruh. Ini sekaligus menepati matlamat utama kajian ini iaitu untuk mereplikasi situasi sebenar dilapangan kedalam simulasi yang dibangunkan.

Terdapat beberapa kajian yang dijalankan untuk menambahbaik aliran pergerakan pengguna melibatkan persekitaran dalaman. Minegishi dan Takeichi (2018) memberi tumpuan kepada pemindahan pengguna dari tempat duduk penonton dalam stadium ke akses keluar. Lebar akses keluar dan situasi pemindahan disimulasikan untuk merekabentuk dasar pengurusan pemindahan orang ramai ketika kecemasan. Lundstrom et al. (2014) membincangkan hubungan antara lebar akses dan tingkah laku pengguna semasa proses pemindahan menggunakan model laluan terowong. Selain itu, Ji et al., (2014) mengesyorkan bahawa lebar akses keluar seharusnya sama dengan lebar akses laluan supaya aliran pemindahan pengguna lebih lancar. Secara amnya, pemilihan laluan yang bergantung pada jarak ke akses keluar dan keupayaan pengguna memainkan peranan penting dalam mencerminkan masa yang perlu diambil untuk memindahkan pengguna (Ding et al., 2016).

Kajian ini memberi tumpuan kepada perancangan dan pengujian pemindahan pengguna melalui simulasi tindakbalas kecemasan 3D yang melibatkan tiga fasa utama iaitu fasa integrasi data, fasa pembangunan dan pengujian jaringan topologi dan fasa analisa simulasi (Rajah 1). Tiga nilai parameter diselaraskan berdasarkan input daripada fasa pertama dan kedua. Parameter seperti kelajuan, pemilihan akses dan kapasiti pengguna digunakan untuk mengetahui kesan perubahan parameter kepada proses pemindahan pengguna. Beberapa cadangan untuk menambahbaik aliran pemindahan akan diuji dan dinyatakan untuk dijadikan rujukan dalam perancangan pengurusan kecemasan bangunan.

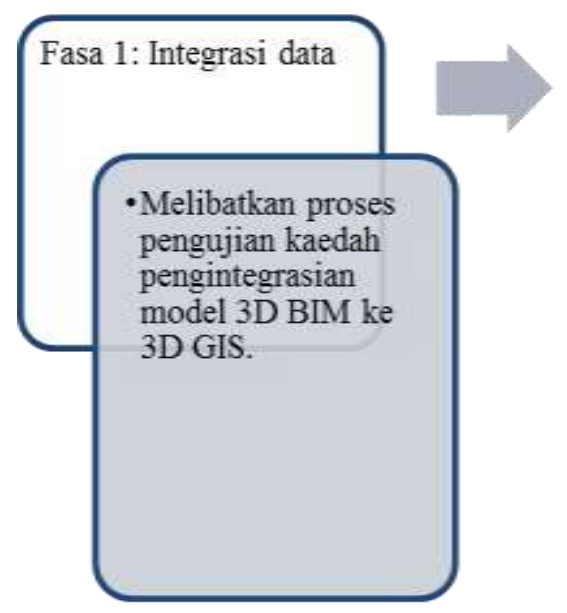

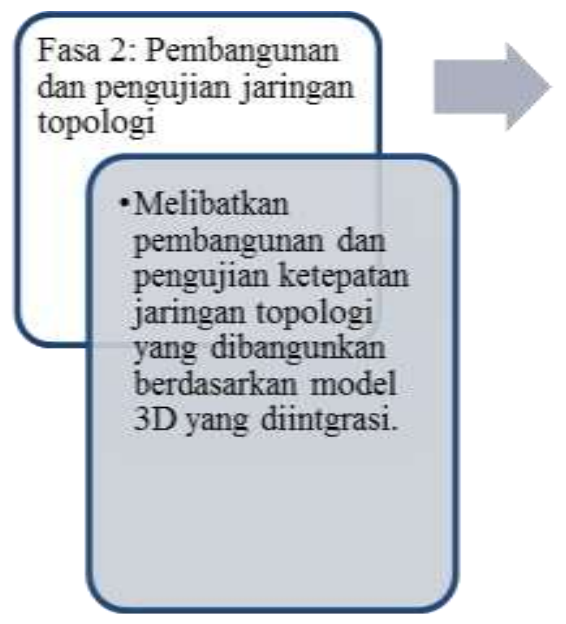

Rajah 1. Fasa-fasa kajian

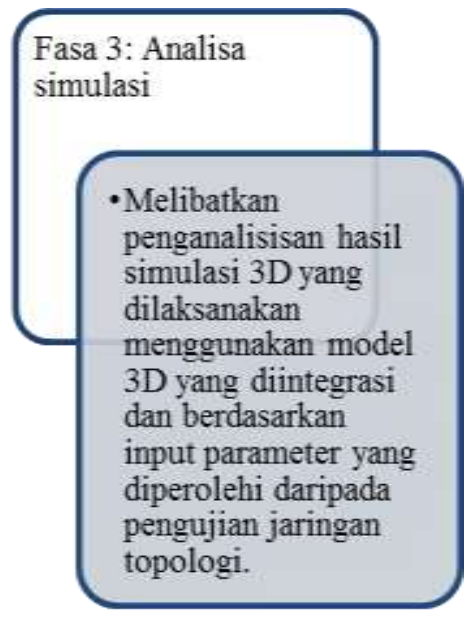


GEOGRAFIA Online ${ }^{\mathrm{TM}}$ Malaysian Journal of Society and Space 16 issue 3 (147-166)

(C) 2020, e-ISSN 2682-7727 https://doi.org/10.17576/geo-2020-1603-12

\section{Hubungan antara BIM dan GIS}

BIM dan GIS adalah dua platfom yang berbeza dimana mempunyai tujuan khusus dalam aplikasi yang tersendiri. BIM pada dasarnya dibina diatas konsep maklumat bangunan yang tidak wujud secara fizikal. Sebaliknya, GIS berdasarkan konsep berbeza kerana ia diwujudkan untuk mewakili objek yang sudah wujud secara fizikal (Nasir et al., 2016). Maklumat terperinci mengenai model 3D BIM membantu GIS untuk memperluaskan skopnya dengan menggunakan analisis spatial pada skala yang lebih baik. Ia juga boleh dijadikan kayu ukur dalam beberapa konteks seperti beberapa kajian aktif mengenai analisis 3D berkaitan dengan pengurusan kecemasan seperti dalam Jadual 1. Ianya digunakan dalam kajian ini untuk mengukur keberkesanan data yang diintegrasi. Secara ringkasnya, BIM menawarkan maklumat spatial dalaman tetapi ia tidak mempunyai fungsi spatial (Zhu et al., 2018) manakala GIS menyampaikan maklumat spatial yang berkaitan dengan persekitaran luar (Teo \& Cho, 2016). Penglibatan BIM yang paling penting kepada GIS adalah menyediakan model bangunan 3D yang komprehensif serta maklumat bangunan yang lengkap. BIM juga boleh mendapat keuntungan daripada keupayaan GIS kerana ia memerlukan beberapa keperluan analisis spatial GIS untuk memperluaskan keupayaannya. Kedua-dua platfom ini boleh mencapai lebih banyak kebaikkan dengan berkolaborasi berbanding bekerja secara berasingan.

Jadual 1. Analisa kajian pengurusan kecemasan

\begin{tabular}{ll}
\hline Kumpulan Analisa & Contoh Analisa \\
\hline Analisa jaringan dalaman & Rangkaian navigasi pemindahan \\
Analisa perkhidmatan berasaskan lokasi & Pengurusan aset dan fasiliti \\
Analisa berasaskan pelan & Liputan sensor tanpa wayar \\
Analisa persekitaran & Analisis liputan penglihatan \\
Analisa faktor dinamik & Analisis api atau asap \\
\hline
\end{tabular}

Sumber: Abdul Rahman \& Abdul Maulud (2019)

\section{Struktur Data 3D}

Secara asasnya, struktur data 3D terdiri daripada dua tahap iaitu tahap geometri dan tahap semantik. Pada tahap geometri, pengkhususan diberikan kepada fizikal sesuatu model itu. Secara umumnya terdapat tiga kategori bagi tahap geometri iaitu boundary representation (B-rep), constructive solid geometry (CSG) dan sweep solid (SS) (Zhu et al., 2018). B-rep menterjemah objek melalui sempadan permukaan merangkumi titik, bucu, permukaan isipadu yang diikat menjadi pepejal 3D. CSG pula digunakan untuk mewakili objek selepas pemprosesan untuk memberi definisi kepadatan pepejal sesuatu model. Ia mempunyai maklumat kepadatan ruang dan berkebolehan untuk analisis 3D ruang dan kebakaran atau asap (Abdul Rahman \& Abdul Maulud, 2019). Perbezaan antara B-rep dengan CSG boleh dilihat dalam Rajah 2. SS merupakan satu bentuk geometri yang dibina bagi mewakili objek yang mempunyai permukaan unik dan melengkung. Ianya berbeza dengan B-rep dan CSG kerana penghasilan SS melibatkan perubahan Euclidean didalam ruang 3D secara konsisten dengan nilai ketinggian objek. Bagi tahap semantik, pengkhususan lebih tertumpu kepada maklumat struktur yang dibina. Sebagai contoh permukaan dinding yang dibina bagi struktur asas dan struktur sementara adalah berbeza dimana 
setiap struktur itu mempunyai maklumat tersendiri seperti ketebalan, jenis struktur dan bahan asas struktur.

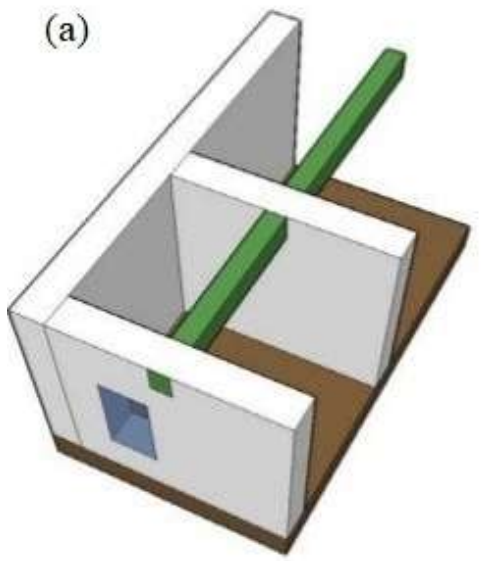

Sumber: Nagel et al., (2009)

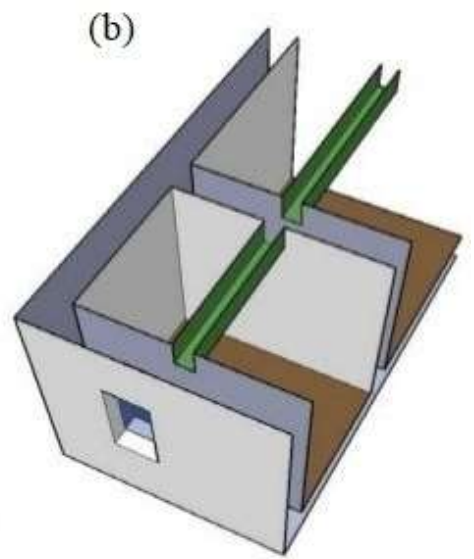

Rajah 2. Perbezaan antara CSG (a) dan B-rep (b)

\section{Struktur Jaringan Topologi}

Setiap rangkaian laluan mempunyai rangkaian topologi yang berfungsi untuk menguruskan maklumat ciri dan mengekalkan hubungan antara ciri-ciri (Taneja et al., 2016). Terdapat dua jenis jaringan asas topologi: topologi berasaskan vektor dan topologi berasaskan grid (Taneja et al., 2016). Topologi berasaskan vektor berfungsi seperti pandangan peta dan analisa yang diaplikasi adalah ringkas. Manakala bagi topologi berasaskan grid adalah digunakan untuk menggambarkan hubungannya dengan penggunaan ruang. Topologi berasaskan grid membentuk susunan nilai dalam matriks mengikut struktur permukaan laluan. Setiap sel grid mewakili komposisi kawasan dan mengandungi ketinggian untuk mewakili nilai permukaan (Joseph, 2002).

Dua pendekatan asas boleh digunakan untuk memaparkan data berasaskan grid iaitu melalui bentuk grid dan bentuk kekisi. Struktur grid menggunakan struktur sel untuk mewakili permukaan. Struktur 2D pada dasarnya mengisi setiap sel dengan nilai-nilai tertentu mengikut sela kontur, sementara struktur 3D mengangkat setiap sel ke ketinggian relatif sebenar sel (Joseph, 2002). Struktur kekisi pula menggunakan garisan jaringan untuk mewakili susunan permukaan. Dalam bentuk 2D, ia membahagikan titik permukaan dengan jarak yang sama berserta maklumat ketinggian garis kontur. Untuk bentuk 3D, setiap persimpangan garis diangkat mengikut kedudukan ketinggian umum seperti yang direkodkan untuk setiap lokasi. Perbezaan antara topologi berasaskan grid dengan berasaskan kekisi boleh dilihat dalam Rajah 3. 


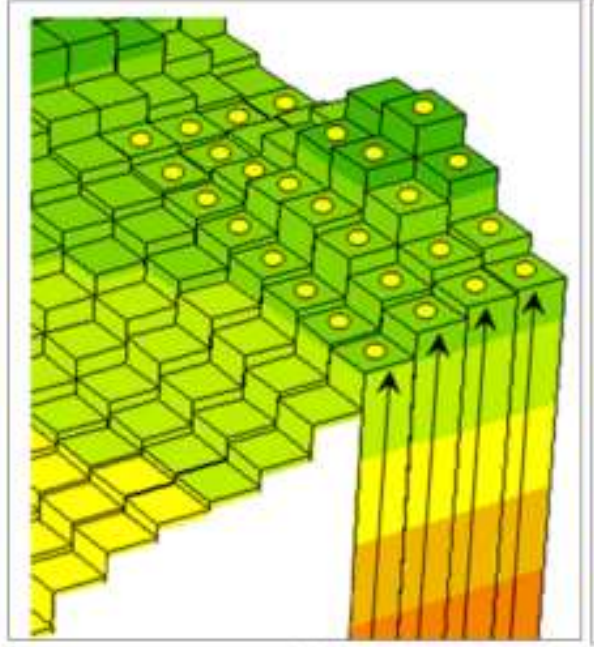

(a)

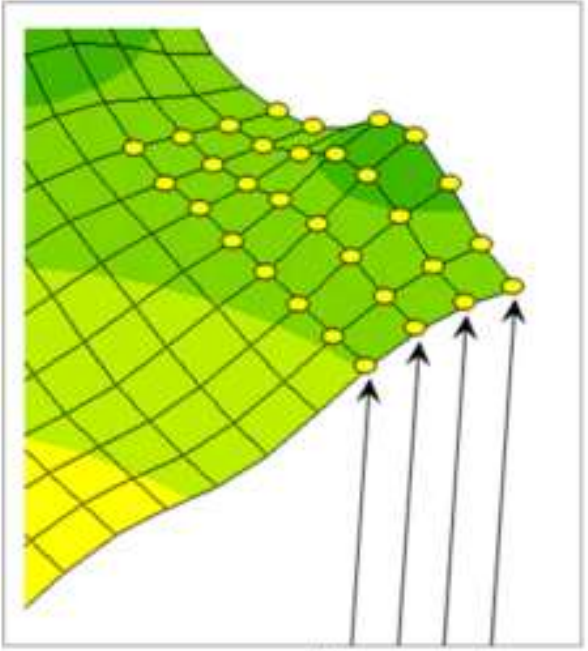

(b)

Sumber: Joseph (2002)

Rajah 3. Konsep asas grid (a) dengan konsep asas kekisi (b)

\section{Level of Service (LOS)}

Level of service (LOS) merupakan salah satu indikator yang sering digunakan dalam menilai kualiti perkhidmatan trafik. Pembahagian kategori LOS bertujuan untuk mengklasifikasi analisa trafik berdasarkan tahap kualiti trafik disesuatu laluan. Pembahagian kategori berdasarkan model LOS oleh John J. Fruin (Fruin, 1971) seperti dalam Rajah 4. Pelbagai kajian dilakukan dengan menggunakan LOS sebagai kayu ukur seperti yang dilakukan oleh Kadali dan Vedagiri (2016) melibatkan penilaian terhadap kualiti trafik untuk lintasan pejalan kaki. Bentuk struktur laluan boleh mempengaruhi kadar aliran pengguna (Campisi et al., 2019) dan kelebaran akses laluan, halangan dan komposisi pengguna mempengaruhi aliran laluan. Oleh itu, penilaian melalui LOS digunakan dalam kajian ini bagi menguji kadar aliran pemindahan pengguna ketika kecemasan supaya langkah penambahbaikan boleh dikenalpasti.

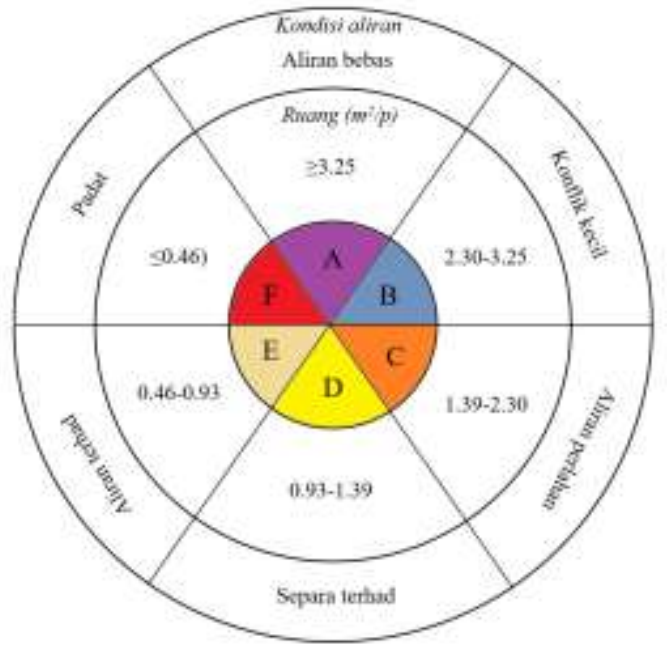

Rajah 4. Pembahagian kategori penggunaan ruang LOS 


\section{Metod}

Terdapat tiga fasa yang terlibat iaitu fasa integrasi data, fasa pembangunan dan pengujian topologi dan fasa analisa simulasi.

\section{Fasa integrasi data}

Fasa pertama melibatkan proses mengintegrasi data model 3D daripada BIM (*.rvt) ke GIS (*.shp). Model Bangunan Prasarana Kampus (BPK) dibangunkan berasaskan pelan seni bina didalam perisian Revit Autodesk didalam format *.rvt. Terdapat tiga kaedah pengintegrasian yang diuji seperti berikut:

a. Kaedah 1: Revit (*.rvt) ke IFC (*.ifc) ke multipatch geometry (*.shp)

b. Kaedah 2: Revit (*.rvt) ke multipatch geometry (*.shp)

c. Kaedah 3: Revit (*.rvt) ke FME Workbench (*.rvz) ke multipatch geometry (*.shp)

Berdasarkan model hasil integrasi daripada ketiga-tiga kaedah tersebut, sebuah penilaian dilakukan berdasarkan kriteria kumpulan analisa aktif 3D yang dilaksanakan seperti dalam Jadual 1. Setiap daripada analisa tersebut mempunyai kaedah yang berbeza tetapi mempunyai tujuan yang sama iaitu pengurusan kecemasan. Penilaian dilakukan terhadap ketersediaan model bagi memenuhi keperluan perancangan pemindahan berdasarkan struktur data 3D (geometri dan semantik).

\section{Fasa pembangunan dan pengujian topologi}

Fasa kedua melibatkan proses topologi berasaskan kekisi seperti yang dicadangkan oleh Li et al. (2010) tetapi didalam persekitaran 3D. Bagi memastikan jaringan kekisi menyeluruh keseluruh permukaan, saiz kekisi yang tepat perlu dikenalpasti. Lima saiz kekisi diuji berdasarkan nilai $5 / 19 \mathrm{~W}, 1 / 4 \mathrm{~W}, 1 / 3 \mathrm{~W}, 1 / 2 \mathrm{~W}$ dan $\mathrm{W}$. W digunakan sebagai pemberat yang diwakili oleh lebar akses $0.950 \mathrm{~m}$ dimana ia merupakan saiz kebanyakkan akses (63\%) di BPK.

Daripada jaringan kekisi yang dibina, ujian ketersediaan dilakukan dimana jaringan laluan kekisi yang dibina dibandingkan dengan jaringan laluan yang dibina melalui kaedah Medial Axis Transformation (MAT) untuk mengenalpasti peratusan ketersediaan laluan aras lantai. Bagi ujian ketepatan, pengujian 13 set jarak dibina dan dibandingkan dengan jarak yang diukur dilapangan. Purata kadar keralatan dikenalpasti bagi setiap saiz kekisi untuk mengenalpasti saiz yang ideal untuk proses pembangunan simulasi.

\section{Fasa analisa simulasi}

Fasa ketiga memberi tumpuan kepada pembangunan simulasi 3D berdasarkan tiga parameter utama iaitu kelajuan, kapasiti pengguna dan pemilihan akses. Lapan simulasi dilaksanakan mengikut gabungan parameter yang berbeza. 
a. Parameter kelajuan

Parameter kelajuan dikira berdasarkan persamaan yang dibangunkan oleh Xiong et al. (2017) seperti berikut:

$$
\mu i=\left\{\begin{array}{cc}
1.4 & \rho \leq 0.75 \\
0.0412 \rho^{2}-0.59 \rho+1.867 & 0.75<\rho \leq 4.2 \\
0.1 & \rho>4.2
\end{array}\right.
$$

$\mu \mathrm{i}$ ialah kelajuan pengguna didalam meter per saat $(\mathrm{m} / \mathrm{s})$ dan $\rho$ ialah kepadatan pengguna berdasarkan pengguna bagi setiap meter per segi $\left(\mathrm{p} / \mathrm{m}^{2}\right)$. $\rho$ boleh dikira berdasarkan saiz dan kawasan yang terlibat. Saiz diambil berdasarkan purata saiz individu seperti yang dinyatakan oleh Xiong et al. (2017) iaitu 0.6m x 0.3m manakala kawasan yang terlibat diambil daripada saiz kekisi yang paling sesuai iaitu $0.38 \mathrm{~m} \times 0.38 \mathrm{~m}$ yang diperolehi daripada fasa pembangunan dan pengujian topologi. Hasil pengiraan, kelajuan pengguna yang paling sesuai digunakan adalah sebanyak $1.19 \mathrm{~m} / \mathrm{s}$.

\section{b. Kapasiti pengguna $\left(d_{l}\right)$}

Parameter kapasiti pengguna dikira berdasarkan jumlah pengguna seramai 155 orang seperti dalam Rajah 5. Siikonen et al. (2001) dalam kajiannya menggunakan nisbah peratusan sebanyak $50 \%$ daripada jumlah kapasiti pengguna (Ciflikli \& Oner Tartan, 2019) tetapi kajian ini, melibatkan dua tahap. Tahap pertama $100 \%\left(d_{l a}\right)$ daripada jumlah pengguna manakala tahap kedua $70 \%\left(d_{l b}\right)$ daripada jumlah pengguna. Ini adalah kerana kapasiti tinggi diperlukan sebagai langkah berjaga-jaga bagi pengurusan kecemasan.
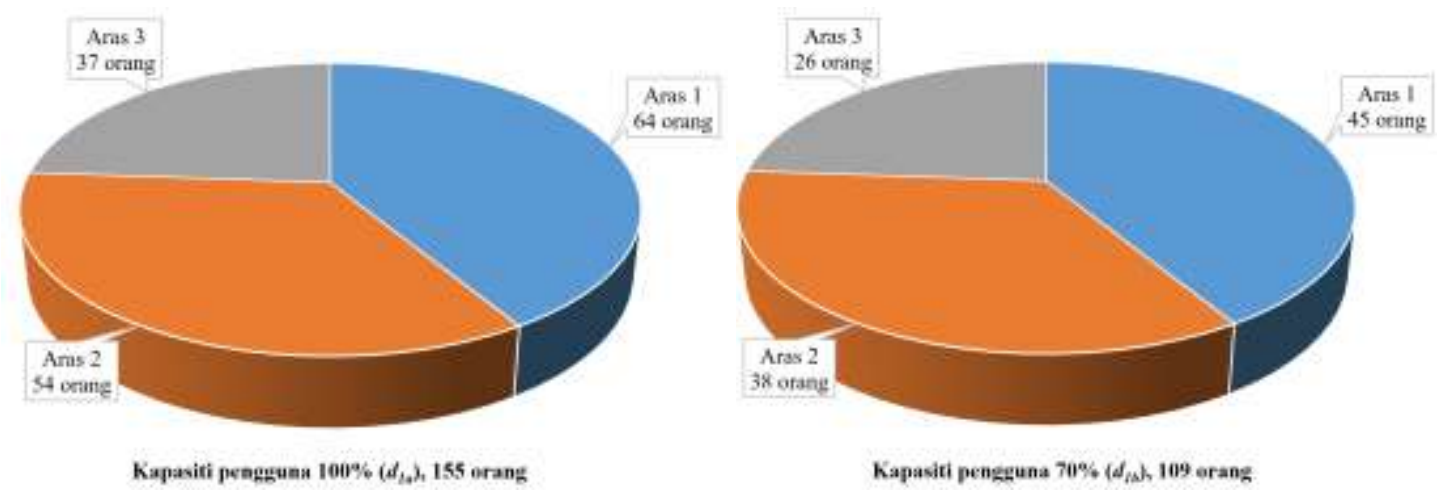

Rajah 5. Kapasiti Pengguna BPK

c. Pemilihan akses $\left(d_{2}\right)$

Parameter pemilihan akses digunakan dalam menilai tingkah laku pengguna seperti yang diterangkan oleh Wang et al. (2014). Ujian dijalankan dalam empat peringkat. Untuk peringkat pertama, pemilihan akses keluar ditetapkan secara rawak $\left(d_{2 a}\right)$. Bagi peringkat kedua pemilihan akses keluar dibagi $\left(d_{2 b}\right)$ oleh zon dengan jarak terhampir pengguna (zon 1 dan zon 2) untuk ke akses keluar seperti dalam Rajah 6. Untuk peringkat ketiga $\left(d_{2 c}\right)$ dan keempat $\left(d_{2 d}\right)$ hanya satu akses digunakan untuk setiap peringkat. Peringkat ketiga menggunakan P1A1, P1A2 dan P1A3 
manakala peringkat keempat menggunakan P2A1, P2A2 dan P2A3 sebagai akses keluar. Kaedah pembahagian zon ini adalah mengambilkira kaedah pembahagian zon Polisi dan Garis Panduan Pelan Bencana Dalaman Pusat Perubatan UKM oleh Unit Keselamatan, Kesihatan dan Persekitaran Pekerjaan (2015).

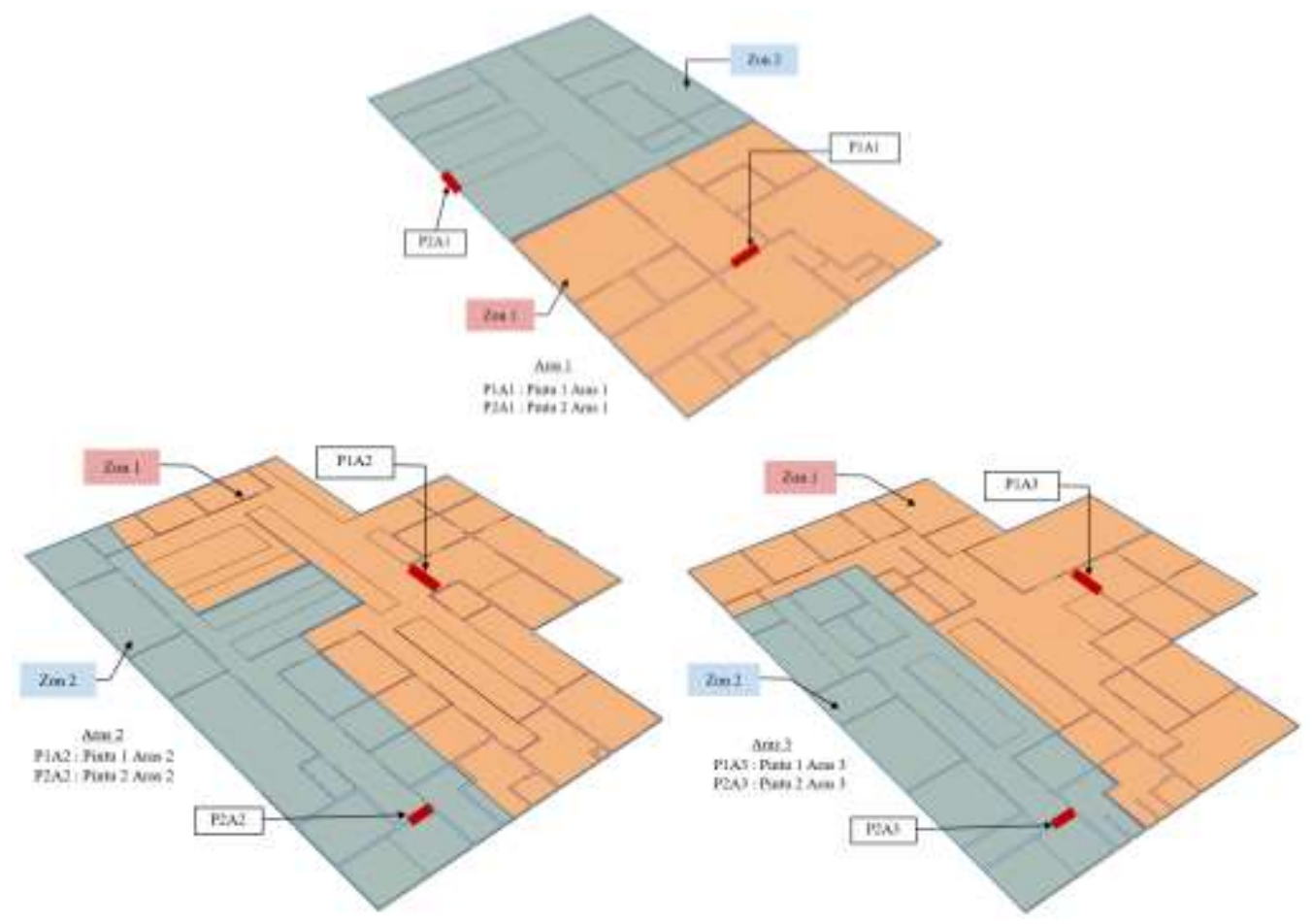

Rajah 6. Pembahagian zon mengikut aras

\section{Pengujian simulasi}

Dengan mengambilkira parameter yang digunakan dalam kajian ini, lapan simulasi dilaksanakan. Perincian keseluruhan input simulasi model adalah seperti dalam Jadual 2.

Jadual 2. Parameter simulasi model

\begin{tabular}{llll}
\hline Kelajuan pengguna & Kapasiti pengguna $\left(\boldsymbol{d}_{\boldsymbol{1}}\right)$ & Pemilihan akses $\left(\boldsymbol{d}_{\mathbf{2}}\right)$ & Simulasi $\left(\boldsymbol{d}_{\boldsymbol{1}}+\boldsymbol{d}_{\mathbf{2}}\right)$ \\
\hline $1.19 \mathrm{~m} / \mathrm{s}$ & Akses bebas $\left(d_{2 a}\right)$ & $d_{1 a} d_{2 a}=S_{1}$ \\
& Bahagi akses $\left(d_{2 b}\right)$ & $d_{1 a} d_{2 b}=S_{2}$ \\
& Akses zon 1 $\left(d_{2 c}\right)$ & $d_{1 a} d_{2 c}=S_{3}$ \\
& Akses zon 2 $\left(d_{2 d}\right)$ & $d_{1 a} d_{2 d}=S_{4}$ \\
& & $d_{1 b} d_{2 a}=S_{5}$ \\
& & $d_{1 b} d_{2 b}=S_{6}$ \\
& & $d_{1 b} d_{2 c}=S_{7}$ \\
& & $d_{1 b} d_{2 d}=S_{8}$ \\
\hline
\end{tabular}




\section{Dapatan kajian}

Bagi memenuhi matlamat utama kajian beberapa cadangan penambahbaikan akan diberikan berdasarkan pengujian yang dilaksanakan.

\section{Dapatan fasa integrasi data}

Daripada tiga kaedah pengintegrasian yang diuji, Kaedah 3: *.rvt ke *.rvz ke *.shp dipilih sebagai kaedah terbaik untuk mengintegrasi model 3D BIM ke GIS. Pemilihan adalah berdasarkan penilaian terhadap faktor-faktor seperti dalam Jadual 3.

Jadual 3. Parameter simulasi model

\begin{tabular}{llll}
\hline \multirow{2}{*}{ Kajian Analisa 3D } & Struktur data 3D & Hasil integrasi \\
\cline { 2 - 3 } & Tahap geometri & Tahap semantik & yang menyokong \\
\hline Analisa jaringan dalaman & B-rep \& SS & Terperinci & Kaedah 1, 2 \& 3 \\
Analisa perkhidmatan berasaskan lokasi & B-rep \& SS & Petengahan & Kaedah 1, 2 \& 3 \\
Analisa berasaskan pelan & B-rep, CSG \& SS & Petengahan & Kaedah 3 \\
Analisa persekitaran & B-rep, CSG \& SS & Terperinci & Kaedah 3 \\
Analisa faktor dinamik & B-rep, CSG \& SS & Terperinci & Kaedah 3 \\
\hline
\end{tabular}

Dapatan fasa pembangunan dan pengujian topologi

Daripada model 3D yang diintegrasi daripada Kaedah 3, pembangunan topologi dilaksanakan berdasarkan lima nilai iaitu 0.250m (5/19W), 0.237m (1/4W), 0.380m (1/3W), $0.475 \mathrm{~m}(1 / 2 \mathrm{~W})$ dan $0.950 \mathrm{~m}(\mathrm{~W})$. Kajian mendapati terdapat jaringan topologi yang tidak menyeluruh ke beberapa kawasan yang terdiri daripada kekisi bersaiz $0.475 \mathrm{~m}$ dan $0.950 \mathrm{~m}$. Oleh itu, jaringan kekisi bersaiz $0.475 \mathrm{~m}$ dan $0.950 \mathrm{~m}$ dikeluarkan daripada pengujian seterusnya kerana tidak memenuhi keperluan kajian. Nilai saiz kekisi $0.380 \mathrm{~m}$ dipilih sebagai saiz paling ideal bagi BPK berdasarkan dapatan ujian ketersediaan dan ujian ketepatan.

\section{a. Ujian ketersediaan}

Bagi ujian ketersediaan, jaringan kekisi yang dihasilkan dipecahkan kepada tiga kategori (Rajah 7) iaitu laluan dalam koridor (hitam), laluan akses ke koridor (biru) dan laluan akses ke kabin (merah). Dapatan daripada ujian ketersediaan adalah seperti dalam Rajah 8. Ketersediaan laluan aras lantai yang dihasilkan jaringan kekisi adalah melebihi jumlah laluan jaringan MAT sebanyak 23\% (78/63). Keputusan ini bukan sahaja didapati daripada ujian bagi aras 3 tetapi juga mengambilkira keputusan daripada aras lain dimana lebihan ketersediaan laluan untuk aras adalah 3\% (33/32) dan untuk aras 2 adalah 9\% (68/62). 
(a)

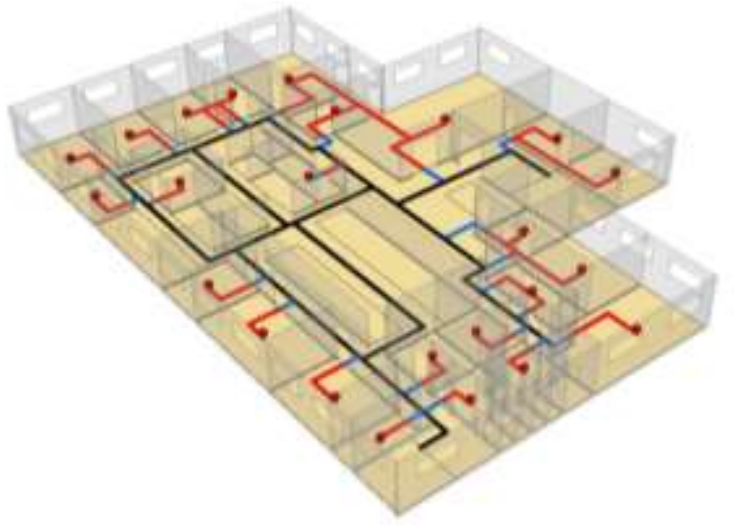

(b)

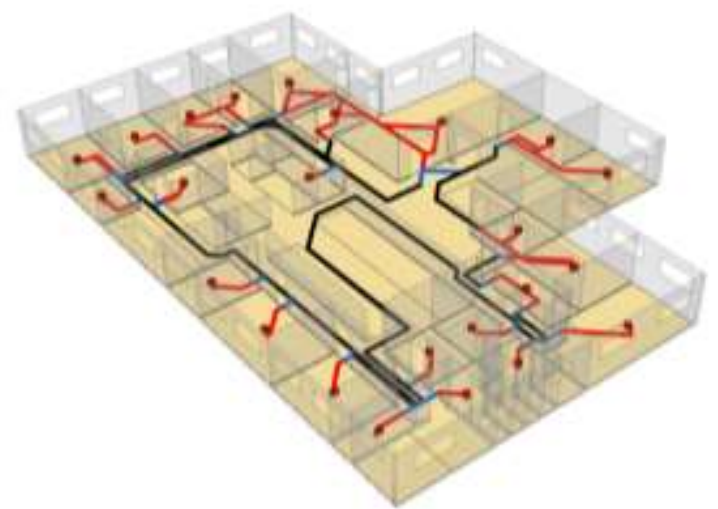

Rajah 7. Ketersediaan ruang dalaman bangunan (a) MAT dan (b) kekisi

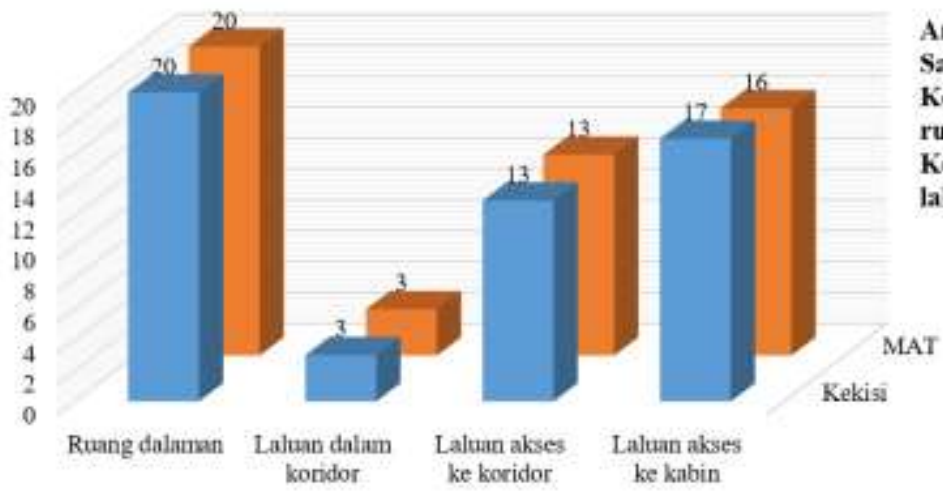
Aras
: Aras 1
Saiz kekisi $\quad: 0.250 \mathrm{~m}$
Ketersediaan
$: 100 \%(20 / 20)$
ruang dalaman
Ketersediaan
$: 103 \%(33 / 32)$
laluan aras lantai

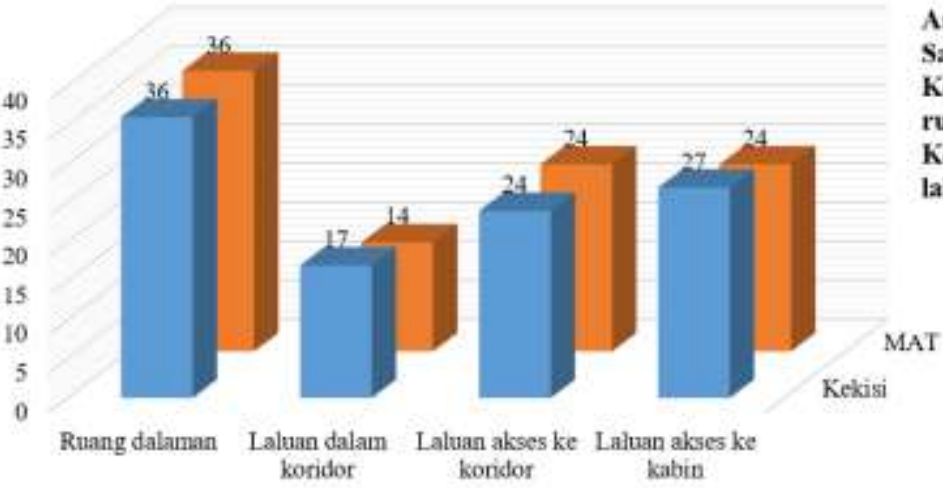

$\begin{array}{ll}\text { Aras } & : \text { Aras } 2 \\ \text { Saiz kekisi } & : 0.237 \mathrm{~m} \\ \text { Ketersediaan } & : 100 \%(36 / 36) \\ \text { ruang dalaman } & \\ \begin{array}{l}\text { Ketersediaan } \\ \text { laluan aras lantal }\end{array} & : 109 \%(68 / 62)\end{array}$

laluan aras lantal

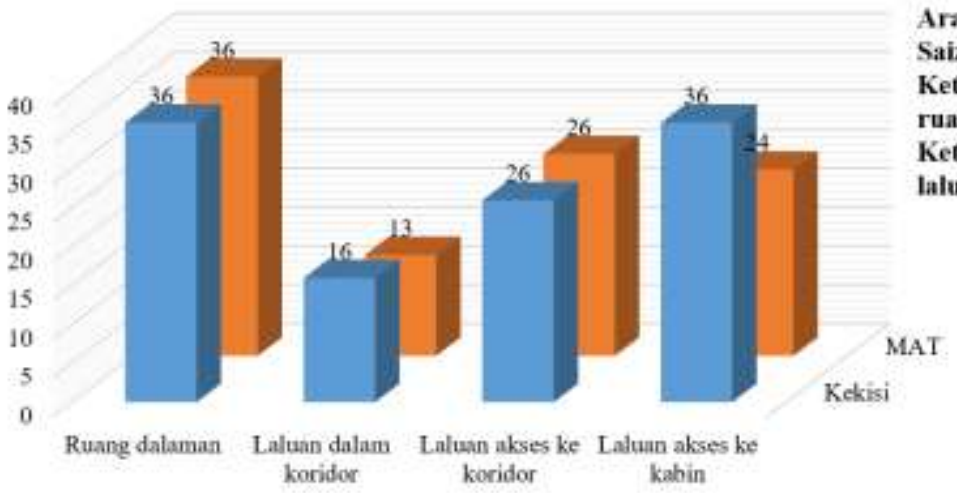

Aras.

: Aras 3

Saiz kekisi $\quad: 0,380 \mathrm{~m}$

Ketersediaan $\quad: 100 \%(36 / 36)$

ruang dalaman

Ketersediaan

$: 123 \%(78 / 63)$

laluan aras lantai

Rajah 8. Keputusan ujian ketersediaan 
b. Ujian ketepatan

Bagi ujian ketepatan, perbandingan 13 set jarak antara jarak jaringan topologi kekisi dengan jarak yang diukur dilapangan dilaksanakan seperti dalam Jadual 4. Berdasarkan kolum kadar ralat, kebanyakan laluan yang dihasilkan oleh kekisi adalah lebih singkat daripada pengukuran sebenar. Ralat negatif mewakili laluan yang dijana singkat daripada laluan pengukuran. Merujuk kepada data yang direkodkan dalam Jadual 4, laluan dengan nombor ID 5 (saiz kekisi 0.250m dan $0.237 \mathrm{~m}$ ) dan nombor ID 9 (saiz kekisi $0.250 \mathrm{~m}$ ), laluan yang dijana daripada kekisi tidak sama dengan laluan yang digunakan oleh pengukur ketika pengukuran. Walau bagaimanapun, semakin meningkat saiz kekisi, laluan yang dijana berubah ke arah laluan yang sama yang digunakan semasa pengukuran di lapangan. Dapat disimpulkan bahawa semakin meningkat saiz kekisi, laluan yang dihasilkan dari kekisi akan beranjak ke laluan tengah koridor menyerupai keadaan yang sama semasa aktiviti cerapan data di lapangan. Data menunjukkan bahawa saiz kekisi $0.380 \mathrm{~m}$ memberi kadar ralat yang paling minima dan dipilih sebagai saiz kekisi yang paling ideal untuk jaringan topologi kekisi. Selain itu, kadar purata keralatan ketiga-tiga saiz kekisi menunjukkan berada dalam kadar penerimaan seperti yang dinyatakan oleh Teo dan Cho (2016) iaitu di bawah 5\%.

Jadual 4. Keputusan ujian ketepatan

\begin{tabular}{|c|c|c|c|c|c|c|c|c|}
\hline \multirow[b]{2}{*}{ ID } & \multirow{2}{*}{$\begin{array}{l}\text { Jarak } \\
\text { (Meter) }\end{array}$} & \multirow{2}{*}{ diukur } & \multicolumn{3}{|c|}{ Jarak dijana (Meter) } & \multicolumn{3}{|c|}{ Kadar ralat (\%) } \\
\hline & & & $\begin{array}{l}0.237 \mathrm{~m} \\
(1 / 4 \mathrm{~W})\end{array}$ & $\begin{array}{l}0.250 \mathrm{~m} \\
(5 / 19 \mathrm{~W}) \\
\end{array}$ & $\begin{array}{l}0.380 \mathrm{~m} \\
(1 / 3 \mathrm{~W})\end{array}$ & $\begin{array}{l}0.237 \mathrm{~m} \\
(1 / 4 \mathrm{~W})\end{array}$ & $\begin{array}{l}0.250 \mathrm{~m} \\
(5 / 19 \mathrm{~W}) \\
\end{array}$ & $\begin{array}{l}0.380 \mathrm{~m} \\
(1 / 3 \mathrm{~W}) \\
\end{array}$ \\
\hline 1 & 18.1 & & 18.2 & 18.0 & 20.1 & 0.55 & -0.55 & 11.05 \\
\hline 2 & 21.9 & & 23.2 & 23.8 & 24.2 & 5.94 & 8.68 & 10.50 \\
\hline 3 & 24.8 & & 24.4 & 24.2 & 24.9 & -1.61 & -2.42 & 0.40 \\
\hline 4 & 27.2 & & 31.0 & 29.2 & 28.3 & 13.97 & 7.35 & 4.04 \\
\hline 5 & 30.3 & & $35.0 *$ & $35.9^{*}$ & 31.6 & 15.51 & 18.48 & 4.29 \\
\hline 6 & 32.6 & & 32.5 & 31.3 & 33.3 & -0.31 & -3.99 & 2.15 \\
\hline 7 & 33.3 & & 32.0 & 31.1 & 33.1 & -3.90 & -6.61 & -0.60 \\
\hline 8 & 35.2 & & 35.2 & 34.6 & 34.3 & 0.00 & -1.70 & -2.56 \\
\hline 9 & 35.5 & & 36.5 & $41.3^{*}$ & 35.5 & 2.82 & 16.34 & 0.00 \\
\hline 10 & 37.0 & & 36.5 & 36.1 & 37.7 & -1.35 & -2.43 & 1.89 \\
\hline 11 & 38.4 & & 38.7 & 38.1 & 38.2 & 0.78 & -0.78 & -0.52 \\
\hline 12 & 39.6 & & 39.0 & 39.5 & 38.3 & -1.52 & -0.25 & -3.28 \\
\hline 13 & 41.2 & & 40.8 & 40.4 & 41.1 & -0.97 & -1.94 & -0.24 \\
\hline \multicolumn{6}{|c|}{ Purata ralat (\%) } & 3.91 & 3.02 & 2.61 \\
\hline
\end{tabular}

*laluan yang dihasilkan daripada kekisi tidak sama dengan laluan yang diukur oleh pengukur.

\section{Dapatan fasa analisa simulasi}

Parameter kelajuan diperolehi daripada pengiraan yang mengambilkira saiz kekisi manakala parameter pemilihan akses membahagi zon berdasarkan jarak yang dikira menggunakan jaringan kekisi. Daripada lapan simulasi yang dilakukan, hasil dapatan dibahagi kepada dua faktor iaitu faktor masa dan faktor ruang kritikal. 


\section{a. Faktor masa}

Tempoh masa lapan simulasi direkodkan dan dibandingkan untuk mengenal pasti punca perbezaan masa ketika proses pemindahan. Terdapat dua perkara yang diteliti iaitu kesan kapasiti pengguna terhadap masa dan kesan pemilihan akses terhadap masa.

Bagi kesan kapasiti pengguna terhadap masa, didapati perbezaan masa antara $S_{1}$ dan $S_{5}$ adalah yang paling minimum seperti dalam Rajah 9. Berbeza dengan perbezaan antara simulasi lain $S_{2}$ dan $S_{6}, S_{3}$ dan $S_{7}$ dan $S_{4}$ dan $S_{8}$ di mana perbezaan masa purata lebih besar daripada 9.00 saat. Keputusan menunjukkan bahawa semakin tinggi masa yang dihabiskan untuk memindahkan pengguna, semakin tinggi kesan kapasiti pengguna semasa kecemasan. Selain itu, aspek pemilihan akses oleh pengguna juga mempengaruhi kerana pilihan akses rawak bebas dari kebergantungan pada pemilihan akses tertentu. Ia membolehkan pengguna membuat keputusan untuk berpindah melalui sebarang akses pada satu masa, tidak seperti simulasi lain yang akses spesifik diputuskan untuk pengguna. Ini disokong oleh penemuan dari tempoh masa pengguna terakhir melalui akses khusus seperti yang ditunjukkan dalam Rajah 10. Tempoh pengguna terakhir melalui keluar P1A1 dan P1A2 untuk $S_{2}$ dan $S_{6}$ berbeza walaupun kedua-duanya mempunyai pemilihan akses keluar yang sama. Ini disebabkan oleh taburan kedudukan pengguna yang tidak sekata yang menjadikan pergerakan pengguna secara umum tidak dapat dikendalikan. Pengagihan pengguna boleh dikawal melalui penstrukturan semula ruang pejabat dengan menyediakan laluan khusus untuk ke akses keluar.

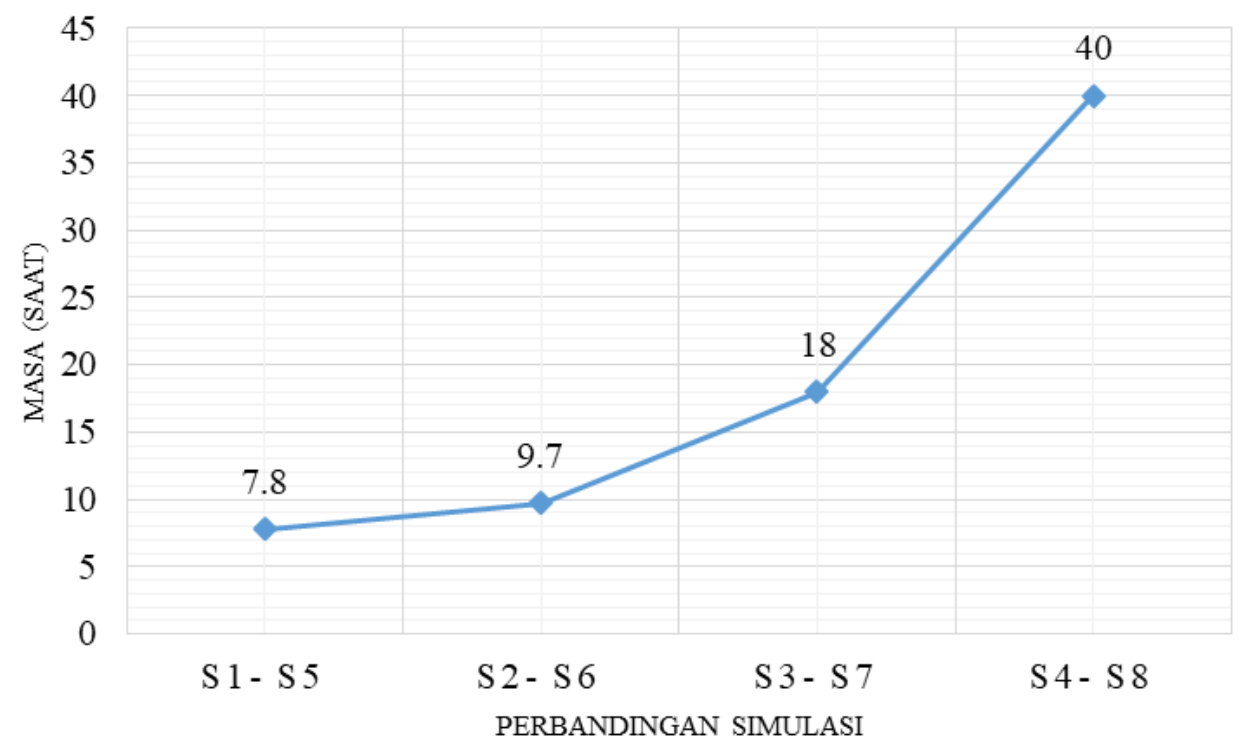

Rajah 9. Kesan perbezaan kapasiti terhadap masa 


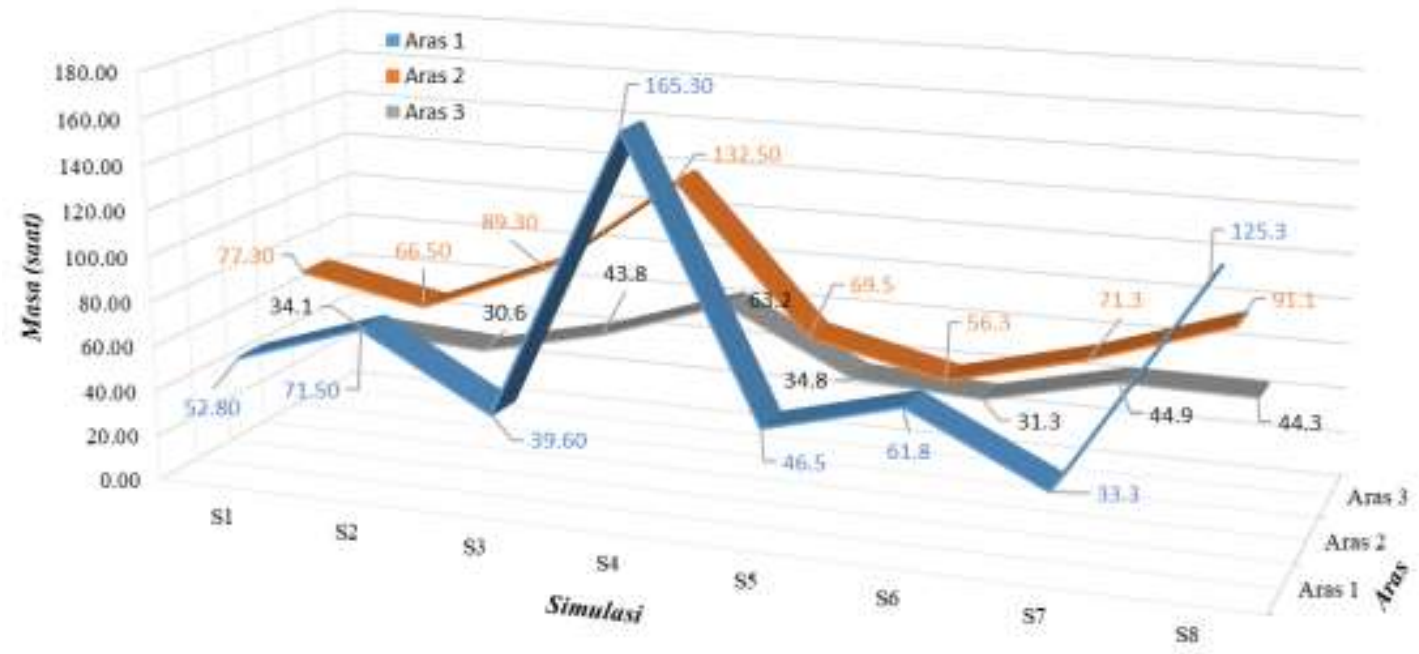

Rajah 10. Masa yang diperlukan untuk keluar dari setiap aras

Bagi kesan pemilihan akses terhadap masa, perbandingan masa keseluruhan yang direkodkan untuk lapan simulasi yang dilakukan ditunjukkan pada Rajah 11. $S_{2}$ dan $S_{6}$ mencatatkan jumlah masa yang paling singkat untuk memindahkan pengguna dimana kedua-dua simulasi mempunyai persamaan dari perspektif pemilihan akses, iaitu bahagi akses. $S_{2}$ mencatatkan masa 71.5 saat dan $S_{6} 61.8$ saat yang lebih singkat berbanding simulasi lain. Kadar ketumpatan penggunaan laluan bagi pembahagian akses juga lebih sekata yang juga menyumbang kesingkatan masa pemindahan pegguna.

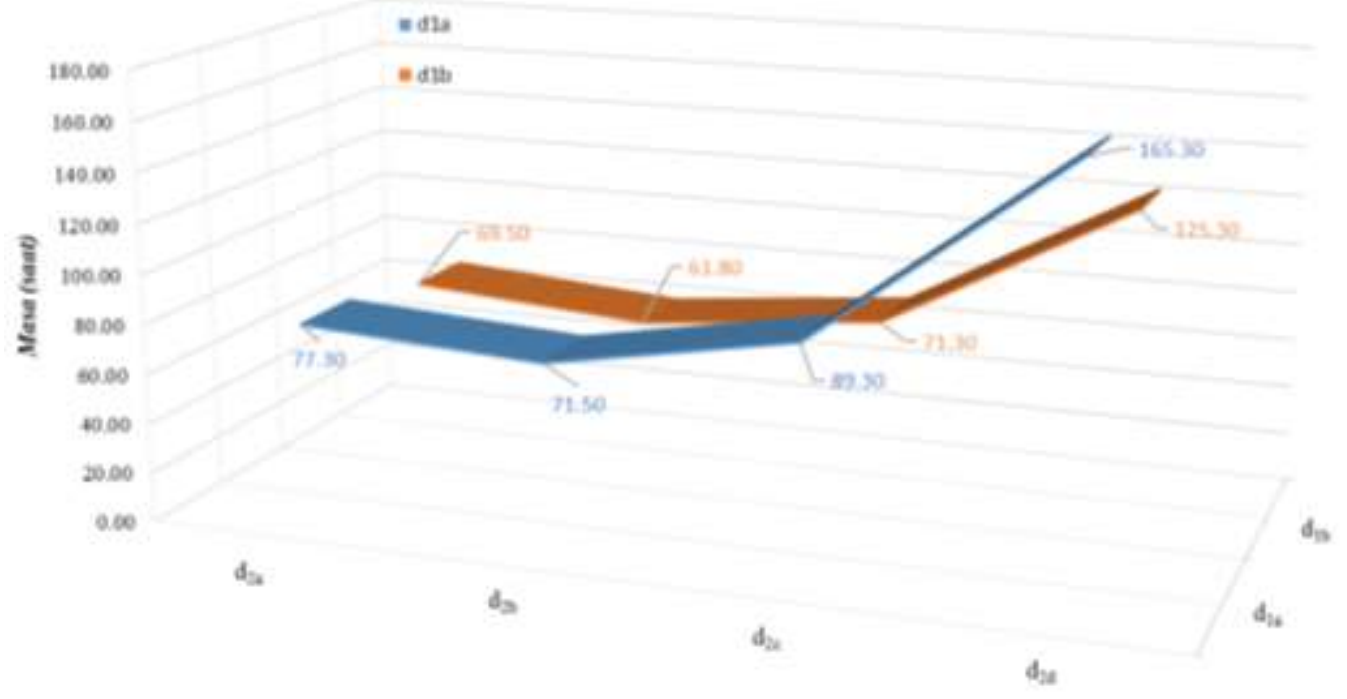

Rajah 11. Masa yang diperlukan untuk keluar dari BPK

\section{b. Faktor ruang kritikal}

Dalam kajian ini, pengenalpastian ruang kritikal adalah berdasarkan korelasi antara peta haba kepadatan laluan dan maklumat penggunaan LOS ruang (Campisi et al., 2019). 
Bagi peta haba kepadatan pengguna aras 1, penilaian adalah berdasarkan kekerapan daripada lapan simulasi. Terdapat dua kawasan yang terlibat dengan kepadatan pengguna 2.01 $\mathrm{p} / \mathrm{m}^{2}$ hingga $3.00 \mathrm{p} / \mathrm{m}^{2}$ iaitu disekitar laluan tangga (tiga kekerapan) dan sekitar P2A1 (lapan kekerapan). Bagi aras 2 pula melibatkan dua kawasan iaitu di laluan akses ke P1A2 (lima kekerapan) dan di laluan ke P2A2 (tiga kekerapan). Sementara bagi aras 3 melibatkan tiga kawasan iaitu di laluan akses P1A3 (tiga kekerapan) dan di laluan P2A3 (tiga kekerapan).

Untuk maklumat kadar LOS di aras 1 secara purata daripada lapan simulasi, keadaan aliran E dikesan disekitar akses P1A1 dan keadaan aliran F dikesan di P2A1. Penggunaan ruang direkodkan melebihi $2.17 \mathrm{p} / \mathrm{m}^{2}$ kerana akses P2A1 tidak dapat menampung bilangan pengguna yang ramai dalam satu-satu masa. Dengan akses berkelebaran $1.2 \mathrm{~m}$, ia hanya boleh menampung satu pengguna pada satu masa. Ini seperti yang dinyatakan oleh Zegeer (2002) bahawa Panduan Pengguna Kemudahan Pejalan Kaki Pentadbiran Persekutuan (FHWA) menyatakan akses berkelebaran minima $1.5 \mathrm{~m}$ akan membolehkan dua orang melaluinya dalam aliran lancar (Quezon \& Kumala, 2018). Ini juga disokong oleh kajian yang dijalankan oleh Pan et al. (2019) di mana lebar akses minimum yang disyorkan untuk melancarkan aliran pemindahan pengguna adalah antara $1.4 \mathrm{~m}$ hingga $1.5 \mathrm{~m}$ lebar. Ini juga terbukti dalam kajian ini apabila akses P2A1 dilebarkan kepada 1.5m, kadar aliran pengguna bertambah baik daripada kadar aliran $\mathrm{F}$ ke kadar aliran E. Pelebaran akses P2A1 juga memberi kesan kepadatan aliran di akses P1A1 di mana aliran kepadatan pengguna yang melalui akses P1A1 bertambah baik dari kadar aliran E ke kadar aliran D. Perbezaan kadar aliran pengguna sebelum dan selepas pelebaran akses boleh dilihat dalam Rajah 12.
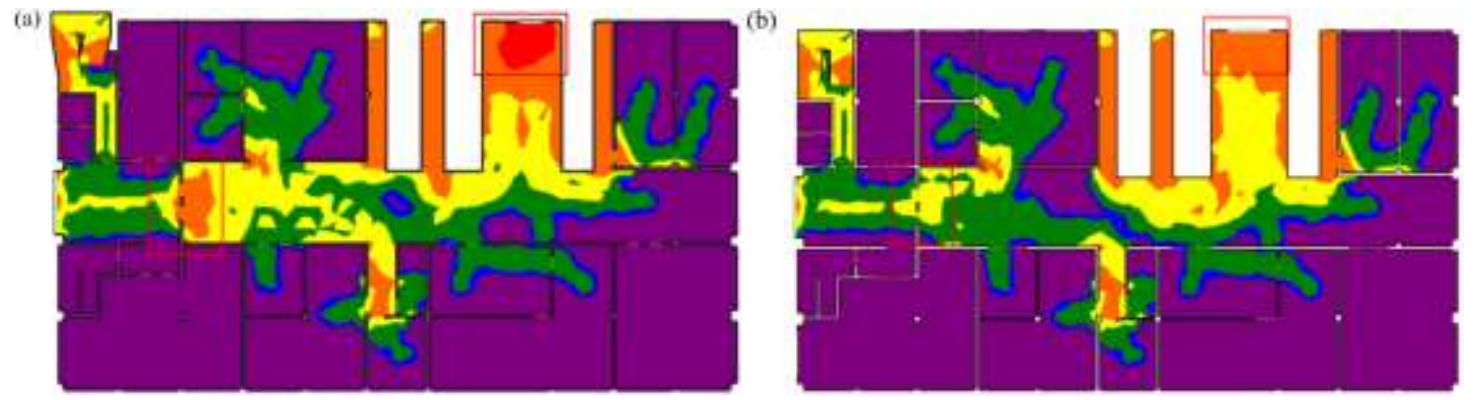

Rajah 12. Kadar aliran pengguna sebelum (a) dan selepas (b) pelebaran akses di aras 1

Untuk aras 2, keadaan aliran E dan F dikesan di laluan ke P1A2. Ruang yang dikenalpasti melibatkan aliran melebihi $2.17 \mathrm{p} / \mathrm{m}^{2}$ disebabkan oleh akses tersebut merupakan akses utama yang menghubungkan ke akses keluar bangunan. P1A2 melibatkan dua akses berkelebaran 0.8m yang dapat menampung satu pengguna dalam satu-satu masa. Untuk mengoptimumkan ruang, pembahagian laluan pengguna boleh dilaksanakan seperti yang dilakukan pada $S_{2}$. Melalui kaedah pembahagian akses $S_{2}$, didapati bahawa kadar aliran adalah dalam kondisi aliran E berbanding simulasi lain yang mencapai kadar aliran F. Penyelesaian ini boleh dicapai dengan menggabungkan dua akses berkelebaran $0.8 \mathrm{~m}$ kepada satu akses berkelebaran $1.6 \mathrm{~m}$ untuk membolehkan dua orang melalui secara aliran bebas (Zegeer, 2002; Pan et al., 2019). Ini juga dibuktikan dalam kajian ini apabila kedua-dua akses disatukan, kadar aliran pengguna bertambahbaik kepada aliran E seperti dalam Rajah 13. 
(a)

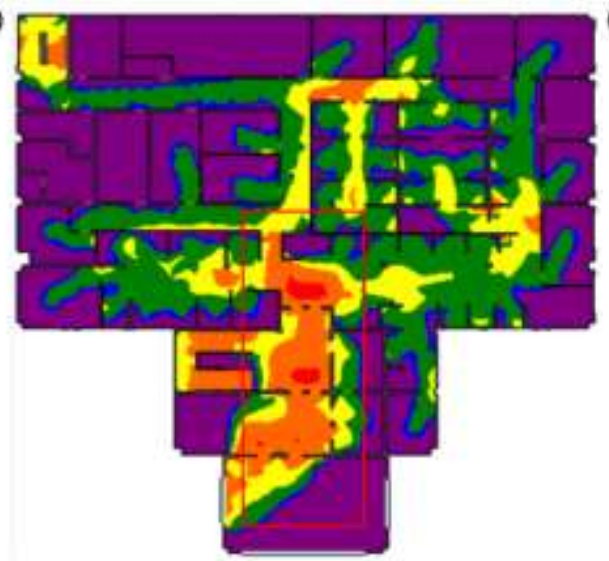

(b)

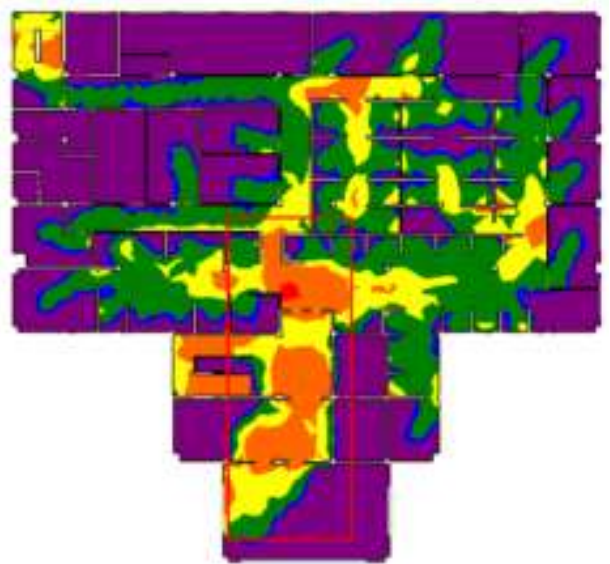

Rajah 13. Kadar aliran pengguna sebelum (a) dan selepas (b) pelebaran akses di aras 2

Untuk aras 3, kadar aliran E dan F dikesan di laluan menuju ke P1A3 yang merupakan akses utama yang menghubungkan aras 3 dan aras 2 melalui tangga. Ia juga disebabkan oleh ruang yang mempunyai dua akses berkelebaran $0.8 \mathrm{~m}$ yang boleh menampung satu pengguna dalam satu-satu masa. Dengan menggabungkan dua akses berkelebaran $0.8 \mathrm{~m}$ kepada akses $1.6 \mathrm{~m}$, ia membolehkan dua orang mengakses laluan dengan aliran bebas seperti yang diterangkan dalam FHWA. Ia turut disokong oleh kajian Pan et al. (2019) dimana lebar minimum akses yang disyorkan adalah $1.4 \mathrm{~m}$ hingga $1.5 \mathrm{~m}$ lebar untuk mengurangkan kepadatan pengguna dalam satusatu masa. Ini juga terbukti dalam kajian ini apabila kedua-dua disatukan, kepadatan aliran pengguna bertambah baik ke aliran E seperti dalam Rajah 14.
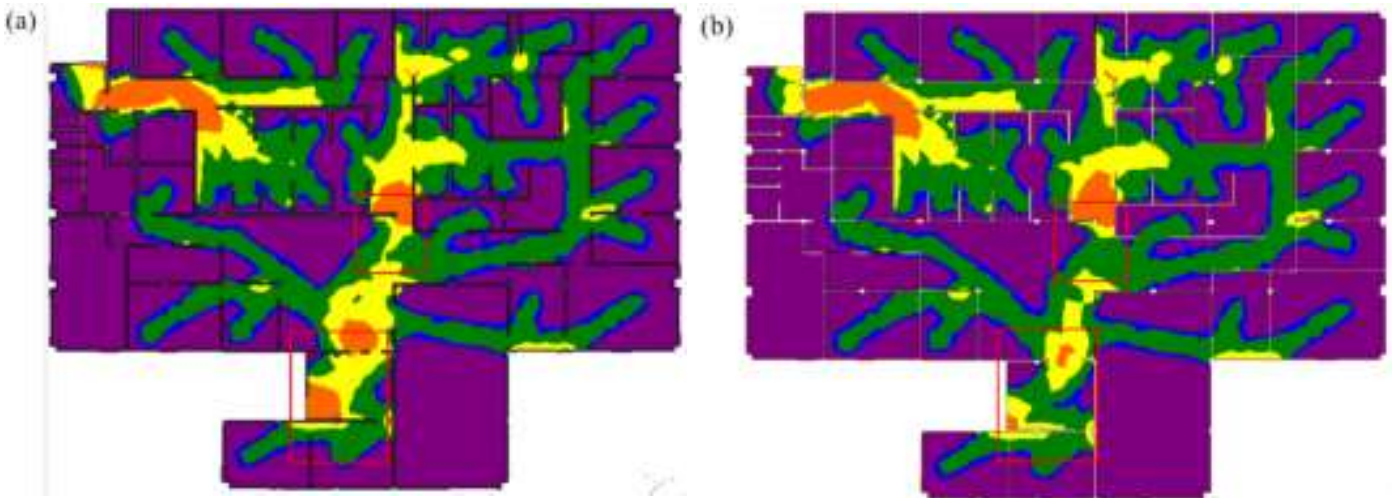

Rajah 14. Kadar aliran pengguna sebelum (a) dan selepas (b) pelebaran akses di aras 3

\section{Perbincangan}

Perkara asas dalam membangunkan simulasi bagi pengujian adalah model bangunan dimana dalam kajian ini, model 3D bangunan diintegrasi daripada BIM. Tiga kaedah telah diuji dan hasilnya dipadankan dengan keperluan semasa analisa yang melibatkan situasi kecemasan untuk menjamin keberkesanan perancangan pemindahan pengguna. Kaedah 3 dipilih sebagai kaedah terbaik kerana memenuhi kedua-dua keperluan (tahap geometri dan tahap semantik) yang diperlukan. Ianya adalah penting dalam memastikan model yang digunakan mempunyai ketepatan geometri yang tinggi bagi dapat menghasilkan simulasi yang menyerupai situasi sebenar dilapangan dan memberi dapatan yang berketepatan tinggi. 
GEOGRAFIA Online ${ }^{\mathrm{TM}}$ Malaysian Journal of Society and Space 16 issue 3 (147-166)

(C) 2020, e-ISSN 2682-7727 https://doi.org/10.17576/geo-2020-1603-12

Seterusnya berdasarkan model yang diintegrasi, proses pembangunan dan pengujian topologi dilaksanakan. Topologi yang dibina diuji dengan dua perkara, perbandingan jaringan dengan topologi MAT (ujian ketersediaan) dan perbandingan dengan pengukuran dilapangan (ujian ketepatan). Hasil daripada ujian ketersediaan mendapati topologi kekisi yang dibangunkan menghasilkan laluan yang lebih daripada MAT secara purata sebanyak 12\%. Lebihan laluan tersebut menunjukkan ketelitian laluan dimana menyerupai pemilihan pengukur semasa melakukan pengukuran dilapangan. Ini membuktikan bahawa lebihan laluan daripada topologi kekisi mencerminkan situasi sebenar pengguna dilapangan. Hasil daripada ujian ketepatan juga memberi ralat dalam kadar yang rendah iaitu secara purata bagi tiga saiz kekisi adalah sebanyak $3.18 \%$ dan disokong oleh kenyatan kajian oleh Teo \& Cho (2016) dimana peratusan kadar keralatan topologi yang baik perlu berada dibawah 5.00\%. Kadar keralatan yang diperolehi membuktikan jaringan topologi kekisi yang dihasilkan menyerupai jaringan laluan sebenar pengguna dilapangan sekaligus mampu menyumbang kepada dapatan simulasi yang baik. Oleh yang demikian, saiz kekisi $0.380 \mathrm{~m}(1 / 3 \mathrm{~W})$ dipilih sebagai saiz yang paling sesuai untuk pembangunan jaringan topologi BPK berdasarkan keputusan ujian ketersediaan dan ujian ketepatan.

Berdasarkan keputusan yang diperolehi daripada pembangunan dan pengujian topologi, saiz kekisi $0.380 \mathrm{~m}$ dan jarak ke akses paling hampir digunakan dalam analisa simulasi. Tiga parameter digunakan dalam simulasi ini iaitu aspek kelajuan, aspek kapasiti pengguna dan aspek pemilihan akses. Aspek kelajuan dikira dengan mengambilkira saiz kekisi serta berdasarkan formula yang dicadangkan oleh Xiong et al. (2017). Penggunaan formula tersebut adalah bagi mengelakkan penggunaan jumlah purata kelajuan pejalan kaki yang berbeza-beza seperti yang dinyatakan oleh Banerjee et al. (2018). Selain itu, penulis juga mengambilkira faktor umur dan kesihatan pengguna BPK yang sekata dalam memilih penggunaan formula tersebut. Penggunaan aspek kapasiti pengguna berdasarkan kaedah yang dicadangkan oleh Siikonen et al. (2001) dimana pengujian mengambilkira kapasiti pengguna 100\% dan 70\% daripada jumlah pengguna BPK. Aspek pemilihan akses pula mengambilkira dua faktor yang diutarakan oleh Wang dan Sun (2014) iaitu jarak terhampir dan masa terpantas. Pemilihan akses adalah berdasarkan analisa spatial terhadap topologi kekisi dan lawatan tapak oleh penulis yang dibahagikan kepada dua zon utama. Kaedah pembahagian zon ini juga adalah mengambilkira kaedah pembahagian zon bagi Pusat Perubatan UKM didalam Polisi dan Garis Panduan Pelan Bencana Dalaman oleh Unit Keselamatan, Kesihatan dan Persekitaran Pekerjaan (2015).

Hasil analisa simulasi dibahagi dalam dua bahagian, faktor masa dan faktor ruang kritikal. Keputusan faktor masa mendapati aspek pemilihan akses memberi kesan terhadap masa yang diambil untuk memindahkan pengguna. Hasil mendapati pembahagian akses mengikut zon mencatatkan masa yang paling pantas iaitu bagi 71.5 saat $\left(S_{2}\right)$ iaitu $17.7 \%$ lebih pantas dan 66.0 saat $\left(S_{6}\right) \quad 17.4 \%$ lebih pantas daripada masa yang paling lewat. Bagi aspek kapasiti pengguna hasil penelitian mendapati bahawa semakin tinggi masa yang digunakan untuk pemindahan pengguna, semakin tinggi kesan terhadap perbezaan kapasiti pengguna dalam memindahkan pengguna. Oleh yang demikian, adalah penting untuk mempunyai perancangan bagi memindahkan pengguna secepat mungkin untuk meminimakan kesan perbezaan kapasiti pengguna sepertimana yang digariskan oleh Jabatan Bomba dan Penyelamat Malaysia (2018). Yang terakhir keputusan daripada faktor ruang kritikal didapati akses ke P2A1 di aras 1, akses ke P1A2 di aras 2 dan akses ke P1A3 di aras 3 perlu diberi perhatian. Ini adalah kerana akses-akses tersebut memberi kesan dalam aliran pemindahan pengguna. Beberapa cadangan seperti pelebaran akses dan pembahagian akses telah diberikan. Cadangan-cadangan berikut juga telah 
diuji dan didapati keputusan yang diperolehi terbukti membantu dalam penambahbaikan aliran proses pemindahan pengguna. Keputusan tersebut turut disokong dengan kajian yang dilaksanakan oleh Pan et al. (2019) berkaitan dengan pengaruh pelebaran akses laluan terhadap aliran pemindahan pengguna. Dengan peralihan pengguna yang lancar terbukti dapat meminimakan kadar risiko kecederaan dan meminimakan resiko panik bagi pengguna (Jabatan Bomba dan Penyelamat Malaysia, 2018).

Bagi menambahbaik proses pemindahan pengguna, langkah-langkah yang dicadangkan perlulah dilaksanakan untuk meminimakan kesan situasi kecemasan terhadap pengguna. Berdasarkan hasil kajian ini didapati beberapa perkara boleh diambil untuk dijadikan rujukan. Antaranya pengurusan rangka kerja untuk pengujian simulasi bagi proses pemindahan pengguna boleh digunakan untuk mendapatkan hasil yang terhampir dengan aplikasi terhadap pengguna dilapangan. Selain itu, dengan pembahagian akses berdasarkan jarak dan masa yang paling pantas boleh dilaksanakan supaya membantu dalam melancarkan proses pemindahan pengguna. Pengenalpastian ruang akses yang boleh ditambahbaik seperti pelebaran ruang akses kerana hasil simulasi yang dijalankan mendapati terdapat impak yang positif daripada pelebaran akses-akses yang dikenalpasti sebagai ruang kritikal.

\section{Kesimpulan}

Asas kajian ini adalah untuk menilai kesan struktur perancangan pemindahan terhadap masa pemindahan pengguna. Pengujian telah dijalankan ke atas BPK dan mengambilkira senario yang berbeza bagi mengenalpasti kesan bagi setiap parameter. Penemuan utama dalam kajian ini termasuk kesinambungan pengujian model 3D, pengujian topologi serta pengenalpastian ruang kritikal diambilkira berdasarkan tingkah laku pemilihan akses untuk memperbaiki aliran pemindahan. Untuk memperbaiki proses pemindahan pengguna, perkara-perkara yang dicadangkan boleh diambil tindakan bagi menambahbaik perancangan pengurusan kecemasan. Dapatan daripada kajian ini boleh membantu pihak-pihak yang berkepentingan untuk membuat perancangan yang teliti khususnya melibatkan perkara-perkara yang boleh dikawal seperti pengurusan ruang dan kapasiti pengguna untuk pengurusan kecemasan. Adalah penting untuk memastikan adanya jalan keluar yang mencukupi dan selamat seperti yang diutarakan dalam Garispanduan Keselamatan Kebakaran Di Premis Perhimpunan Awam oleh Jabatan Bomba dan Penyelamat (2018). Penentuan kepenggunaan ruang terutama kepada ruang yang berisiko dapat di tentukan supaya pengurusan ketika kecemasan dapat diuruskan tanpa masalah. Tambahan juga, rangka kerja yang dilaksanakan dalam kajian turut boleh digunapakai dalam aktiviti pengauditan penggunaan ruang dalam bangunan. Ianya sedikit sebanyak dapat membantu dalam memastikan susunatur struktur penggunaan bangunan tidak mengganggu proses pemindahan pengguna ketika kecemasan.

\section{Penghargaan}

Penghargaan kepada Universiti Kebangsaan Malaysia atas pembiayaan geran bernombor KRA2018-019 dan DIP-2018-030. Terima kasih kepada Pusat Pencerapan Bumi, Institut Perubahan Iklim dan Prasarana, Universiti Kebangsaan Malaysia atas bimbingan semasa proses menjalankan kajian ini.

\section{Rujukan}


GEOGRAFIA Online ${ }^{\mathrm{TM}}$ Malaysian Journal of Society and Space 16 issue 3 (147-166)

(C) 2020, e-ISSN 2682-7727 https://doi.org/10.17576/geo-2020-1603-12

Abdul Rahman, S.A.F.S. \& Abdul Maulud, K.N. (2019). Approaching BIM-GIS integration for $3 \mathrm{D}$ evacuation planning requirement using multipatch geometry data format. IOP Conference Series: Earth and Environmental Science, 385, 012033.

Abdul Rahman, S.A.F.S., Abdul Maulud, K.N., Syed Mustorpha, S.N.A \& Abdul Halim, N.Z. (2020). Implication of pre-evacuation time based on 3D evacuation simulation by integrated BIM and GIS. International Journal of Advanced Science and Technology, 29(05), 6988-7002.

Banerjee, A., Maurya, A. K., Lammel, G. (2018). Pedestrian flow characteristics and level of service on dissimilar facilities: A critical review. Journal of Collective Dynamics, 4.

Campisi, T., Canale, A., Tesoriere, G., Lovric, I. \& Čutura, B. (2019). The importance of assessing the level of service in confined infrastructures: some considerations of the old ottoman pedestrian bridge of mostar. Applied Sciences, 9(8), 1630.

Ciflikli, C. \& Oner Tartan, E. (2019). A model for the visualization and analysis of elevator traffic. Transportation Planning and Technology, 1-13.

Ding, N., Chen, T. \& Zhang, H. (2016). Simulation of high-rise building evacuation considering fatigue factor based on cellular automata: A case study in China. Building Simulation, 10(3), 407-418.

Fruin, J.J. (1971). Designing for pedestrians: a level of service concept, Washington: Transportation Research Board Business Office.

Jabatan Bomba dan Penyelamat Malaysia. (2018). Garis Panduan Keselamatan Kebakaran di Premis Perhimpunan Awam. Diambil daripada http://www.bomba.gov.my/index.php/pages/view/146

Ji, J., Meng, Y., Li, Q. \& Yang, S. (2014). Study on factors affecting evacuation capability of a fire-protection walk in underground buildings. Procedia Engineering, 71, 357-363.

Joseph, K.B. (2002). Map Analysis, Understanding spatial patterns and relationships, 18, $26-27$.

Kadali, R.B \& Vedagiri, P. (2016). Review of the pedestrian level of service: Perspective in developing countries. Transp. Res. Rec. J. Transp. Res. Board, 2581, 37-47.

Kadir, A., Abudin, R. \& Razman, M.R. (2019). Penilaian iklim keselamatan persekitaran kerja terhadap komuniti kakitangan kerajaan di Putrajaya. Geografia-Malaysian Journal of Society and Space, 15.4 .

Kneidl, A., Borrmann, A. \& Hartmann, D. (2012). Generation and use of sparse navigation graphs for microscopic pedestrian simulation models. Advanced Engineering Informatics, 26(4), 669-680.

Li, X., Claramunt, C. \& Ray, C. (2010). A grid graph-based model for the analysis of 2D indoor spaces. Computers, Environment and Urban Systems, 34(6), 532-540.

Lin, W.Y. \& Lin, P.H. (2018). Intelligent generation of indoor topology (i-GIT) for human indoor pathfinding based on IFC models and 3D GIS technology. Automation in Construction, 94, 340-359.

Lundstrom, F.V., Ahlfont, J. \& Nilsson, D. (2014). The effect of raised walkway design on evacuation behavior in rail tunnels. Fire Saf. Sci, 11, 1091-1102.

Minegishi, Y. \& Takeichi, N. (2018). Design guidelines for crowd evacuation in a stadium for controlling evacuee accumulation and sequencing. Japan Architectural Review.

Nagel, C., Stadler, A. \& Kolbe, T.H. (2009). Conceptual requirements for the automatic reconstruction of building information models from uninterpreted 3D models. The 
International Archives of the Photogrammetry, Remote Sensing and Spatial Information Sciences, 34.

Nasir, N.A., Maulud, K.N., \& Yusoff, N.I. (2016). Geospatial analysis of road distresses and the relationship with the slope factor. Journal of Engineering Science and Technology, 11, 655-665.

Pan, Z., Wei, Q., Torp, O. \& Lau, A. (2019). Influence of evacuation walkway design parameters on passenger evacuation time along elevated rail transit lines using a multi-agent simulation. Journal of Sustainability, 11(21), 6049.

Quezon, E. \& Kumala, T. (2018). Investigation of pedestrian safety problems and its countermeasures: A case study in Nekemte City, Ethiopia. International Journal of Engineering and Technical Research (IJETR), 8, 58-64.

Siikonen, M-L., Susi, T. \& Hakonen, H. (2001). Passenger traffic flow simulation in tall buildings. Elev. World, 49(8), 117-123.

Taneja, S., Akinci, B., Garrett, J. H. \& Soibelman, L. (2016). Algorithms for automated generation of navigation models from building information models to support indoor map-matching. Automation in Construction, 61, 24-41.

Teo, T.A. \& Cho, K.H. (2016). BIM-oriented indoor network model for indoor and outdoor combined route planning. Advanced Engineering Informatics, 30(3), 268-282.

Unit Keselamatan, Kesihatan dan Persekitaran Pekerjaan. (2015). Polisi Dan Garis Panduan Pelan Bencana Dalaman, Pusat Perubatan UKM.

Volk, R., Stengel, J. \& Schultmann, F. (2014). Building information modeling (BIM) for existing buildings - Literature review and future needs. Automation in Construction, 38, 109-127.

Xiong, Q., Zhu, Q., Du, Z., Zhu, X., Zhang, Y., Niu, L. \& Zhou, Y. (2017). A dynamic indoor field model for emergency evacuation simulation. ISPRS International Journal of GeoInformation, 6(4), 104.

Zegeer, V.C. (2002). Pedestrian facilities users guide: providing safety and mobility. US Department of Transportation, Federal Highway Administration (FHWA): McLean, VA, USA.

Zhu, J., Wright, G., Wang, J. \& Wang, X. (2018). A critical review of the integration of geographic information system and building information modelling at the data level. ISPRS International Journal of Geo-Information, 1-16. 